\title{
Chemopreventive effects of PBI-Se, a selenium-containing analog of PBIT, on AOM-induced aberrant crypt foci in F344 rats
}

\author{
NAVEENA B. JANAKIRAM ${ }^{1}$, ALTAF MOHAMMED ${ }^{1}$, DURGADEVI RAVILLAH ${ }^{1}$, CHANG IN CHOI $^{1}$, \\ YUTING ZHANG $^{1}$, DHIMANT DESAI ${ }^{2}$, SHANTU AMIN $^{2}$ and CHINTHALAPALLY V. RAO ${ }^{1}$ \\ ${ }^{1}$ Center for Cancer Prevention and Drug Development, Hematology/Oncology Section, \\ Department of Medicine, University of Oklahoma Health Sciences Center, Oklahoma City, OK 73104; \\ ${ }^{2}$ Department of Pharmacy, The Pennsylvania State University College of Medicine, Hershey, PA 17033, USA
}

Received March 6, 2013; Accepted March 26, 2013

DOI: $10.3892 / o r .2013 .2483$

\begin{abstract}
Inducible nitric oxide synthase (iNOS) is a potential target for the treatment of inflammation and cancer. Previously, we showed that the selective iNOS inhibitor $S, S^{\prime}$-1,4-phenylenebis(1,2-ethanediyl)bis-isothiourea (PBIT) caused significant inhibition of colon carcinogenesis induced by azoxymethane (AOM), although it did not completely abrogate NO production due to the exogenous bioavailability of $\mathrm{NO}$ and NO generation by eNOS in tumor tissues. To create an iNOS-targeting molecule that may have additional benefits, a novel isosteric analog of PBIT, PBI-Se, was developed, in which sulfur was replaced with selenium. Chemopreventive efficacy of PBI-Se was evaluated in an AOM-induced rat colon carcinogenesis model using aberrant crypt foci (ACF) as the endpoint. At 7 weeks of age, rats (12/group) were fed the control diet (AIN 76A) and then colonic ACF were induced with two AOM treatments. Three days later, rats were fed diets containing PBI-Se (0-20 ppm) for 8 weeks, and then ACF were evaluated histopathologically. Dietary administration of 10 or 20 ppm of PBI-Se significantly suppressed AOM-induced total colonic ACF formation ( 32 or $41 \%, \mathrm{P}<0.002-0.0003$ ), and multicrypt (4 or more) aberrant foci (29 or $47 \%, \mathrm{P}<0.01-0.0004)$, respectively. The inhibition by $\mathrm{PBI}-\mathrm{Se}$ was dose-dependent and was half the dose of PBIT for inhibiting total ACF in rats. Both PBIT and PBI-Se induced dose-dependent apoptosis in $\mathrm{CaCo} 2$ cells and caused a significant decrease in the cell cycle proteins cyclin D1 $(70 \%, \mathrm{P}<0.0001)$ and iNOS $(99 \%$, $\mathrm{P}<0.0001)$. Treatment with PBIT (30 and $60 \mu \mathrm{M})$ and PBI-Se (2 and $4 \mu \mathrm{M})$ significantly decreased the LPS-induced cytokine interleukin-6 level. Incorporation of selenium into the structure of PBIT provided the agent with additional novel cytotoxic and immunologic properties. Results from the in vitro and in vivo
\end{abstract}

Correspondence to: Dr Chinthalapally V. Rao, OU Cancer Institute, University of Oklahoma Health Sciences Center, BRC Building II, Room 1203, 975 NE 10th Street, Oklahoma City, OK 73104, USA

E-mail:cv-rao@ouhsc.edu

Key words: colon cancer, chemoprevention, iNOS inhibitor, aberrant crypt foci, selenium bioassays suggest that PBI-Se could be developed further for the prevention and treatment of colon cancer.

\section{Introduction}

Colon cancer is the second most common cancer diagnosed in both men and women in the United States, resulting in $\sim 55,000$ deaths a year (1). It is considered one of the most preventable types of cancers as several modifiable environmental factors have been identified to play important roles in the development of this disease. These include specific dietary components such as selenium, an important micronutrient that can protect colonic cells against a wide range of external and internal stressors. Selenium has been reported to inhibit the growth of malignant colonic cells as well as to induce their demise.

Control of inflammatory conditions can also impact colon carcinogenesis. Inflammation favors tumorigenesis by stimulating angiogenesis (2), damaging DNA $(3,4)$, and chronically stimulating cell proliferation $(5,6)$. Proinflammatory genes have been shown to be important for the maintenance and progression of colorectal cancer (CRC) (7). Proinflammatory cytokines bind to specific receptors and activate various signal transduction pathways in the epithelial cells as well as in interacting immune cells, leading to upregulation of prostaglandin synthase 2 (PTGS2), interleukin (IL)-4, IL-6 and $I L-8$ genes (8). These genes have been shown to exhibit proinflammatory activity in the intestine $(9,10)$. These findings support the regular use of non-steroidal anti-inflammatory drugs (NSAIDs) such as aspirin or ibuprofen, which are associated with a 40-50\% decrease in the relative risk for colon cancer (11).

Nitric oxide (NO) has been implicated in the carcinogenic process, particularly in colon or intestinal epithelial cell lines $(12,13)$ and in the known impairment of regulatory processes in these cells (14). The calcium-independent, inducible form of nitric oxide synthase (iNOS) can be induced in many different cell types by cytokines and bacterial lipopolysaccharides (LPS). Once expressed, iNOS can produce sustained and substantial amounts of NO, which can be cytotoxic $(15,16)$. Recently, natural and synthetic drugs that inhibit iNOS and both the NF- $\mathrm{BB}$ and STAT3 pathways (17) 
have been shown to reduce intestinal inflammation in patients and in rodents with inflammatory bowel disease (IBD). Chemically induced colonic inflammation and formation of aberrant crypt foci (ACF, early precursor lesions of colon cancer) also were diminished in animal models administered the iNOS inhibitor $S, S^{\prime}$-1,4-phenylenebis(1,2-ethanediyl)bisisothiourea (PBIT) (18).

To create a more potent compound for inhibition of colon cancer, a novel isosteric analog of PBIT, $S, S^{\prime}-1,4$ phenylenebis(1,2-ethanediyl) bis-isoselenourea (PBI-Se) was synthesized, in which sulfur was replaced with selenium. Incorporation of selenium into the structure of PBIT provided the agent with additional novel properties at very low concentrations. To investigate the efficacy of these iNOS inhibitors for CRC, we first examined the effect of PBI-Se and PBIT on the well-differentiated human intestinal epithelial Caco-2 cell line stimulated with a defined cytokine mixture (consisting of interferon $\gamma$ (IFN $\gamma$ ), interleukin (IL)-1 $\beta$ and tumor necrosis factor $\alpha(\mathrm{TNF} \alpha)$ or with lipopolysaccharide (LPS) and monitored inhibition of growth, induction of apoptosis, and production of key proinflammatory signaling molecules (IL-8 and IL-6). Most human intestinal cell lines studied are poorly differentiated under standard growth conditions. The Caco-2 cell line is considered to resemble normal intestinal epithelial cells (19). LPS and the cytokine mixture have been shown to increase IL-8, IL-6 and iNOS production $(20,21)$. We also examined the chemopreventive efficacy of PBIT and PBI-Se in an azoxymethane (AOM)-induced rat colon carcinogenesis model using ACF as an endpoint biomarker, and we tested the influence of PBI-Se on immune cells.

\section{Materials and methods}

Cell culture and reagents. Caco-2 cells were obtained from the American Type Culture Collection (ATCC, Manassas, VA, USA) and used between passages 30 and 35. Cells were grown in Dulbecco's modified Eagle's medium (DMEM) with $4 \mathrm{mM}$ L-glutamine, 20\% heat-inactivated foetal bovine serum (FBS) and $1 \%$ non-essential amino acids. Cells were cultured at $37^{\circ} \mathrm{C}$ in a water-saturated atmosphere of $95 \%$ air and $5 \% \mathrm{CO}_{2}$, re-fed every 2 days and passaged weekly. Caco- 2 cells were used at 21 days after confluence as indicated, to permit differentiation. PBIT and PBI-Se were provided by Dr Dhemant Desai and were dissolved in phosphate-buffered saline (PBS). The primary antibodies for cyclin D1 and proliferating cell nuclear antigen (PCNA) were obtained from Santa Cruz Biotechnology, Inc. (Santa Cruz, CA, USA). The anti-rabbit antibody and ECL detection system were from Amersham (Arlington Heights, IL, USA). Ethidium bromide and acridine orange were from Sigma (St. Louis, MO, USA).

Cell induction and treatment. Cells were grown as indicated above. At $\sim 70 \%$ confluence and 21 days, cultures were switched to serum-free medium for $24 \mathrm{~h}$. The serum-free medium was removed and the cell monolayer was washed with PBS ( $\mathrm{pH} 7.4)$ prior to addition of cytokines and LPS with PBIT or PBI-Se in fresh medium without serum. Based on a previous study (21), the cytokine concentrations used for induction were IFN $\gamma$ $(200 \mu \mathrm{g} / \mathrm{ml})$, IL-1 $\beta(5 \mathrm{ng} / \mathrm{ml})$ and TNF $\alpha(100 \mathrm{ng} / \mathrm{ml})$; the LPS concentration was $1 \mu \mathrm{g} / \mathrm{ml}$.
Assay of the effect of PBI-Se and PBIT on cell viability. After teatment with PBIT or PBI-Se, cells were harvested and dissociated in a solution of $0.25 \%$ trypsin and $3 \mathrm{mM}$ ethylene diamine tetraacetic acid (EDTA) in PBS, pH 7.4 (without calcium and magnesium). Trypan blue was added and cells were counted with a hemocytometer. Only cells that excluded the dye were counted as viable. Results are expressed as the number of viable cells/ml.

Detection of apoptosis. Cells were exposed to PBIT $(0,30,60$ and $100 \mu \mathrm{M})$ and PBI-Se $(0,2,4$ and $6 \mu \mathrm{M})$ for $24 \mathrm{~h}$. Acridine orange/ethidium bromide ( $1 \mu 1$ of a stock prepared from one part each of $100 \mu \mathrm{g} / \mathrm{ml}$ acridine orange and $100 \mu \mathrm{g} / \mathrm{ml}$ ethidium bromide in PBS) was added to the cell suspension (25 $\left.\mu \mathrm{l} ; 5 \times 10^{6} / \mathrm{ml}\right)$ just before microscopy. A $10-\mu 1$ aliquot of the gently mixed suspension was placed on microscope slides, covered with glass coverslips, and examined under an Olympus AX71 microscope connected to a digital imaging system with SPOT RT software version 3.0. Cells were scored according to the following categories: $\mathrm{C}$ 1, cells with large, green, non-condensed nuclei defined as non-apoptotic, viable cells; C2, cells with red/orange nuclei showing signs of nuclear bead formation defined as apoptotic cells; and C3, cells with large red nuclei not showing signs of nuclear condensation or bead formation defined as necrotic cells. At least 200 cells per sample were counted and scored. The apoptotic index (\%) was calculated by dividing the sum of apoptotic cells (C2) x 100 by the total number of cells scored.

Reverse transcription-PCR for $I L-6$ and $I L-8$. Caco 2 cells were treated with cytokine mixture and LPS plus subtoxic concentrations of PBIT and PBI-Se for $24 \mathrm{~h}$. Total RNA from the treated and untreated samples was extracted using ToTally RNA $^{\mathrm{TM}}$ kit (Ambion) as per the manufacturer's instructions. Equal quantities of DNA-free RNA were used for reverse transcription reactions for cDNA conversion using the SuperScript ${ }^{\mathrm{TM}}$ Reverse Transcriptase (Invitrogen). PCR conditions for IL- 8 amplifications were denaturation at $94^{\circ} \mathrm{C}$ for $2 \mathrm{~min}$, followed by 50 cycles at $95^{\circ} \mathrm{C}$ for $15 \mathrm{sec}, 55^{\circ} \mathrm{C}$ for $10 \mathrm{sec}$ and $72^{\circ} \mathrm{C}$ for $20 \mathrm{sec}$; PCR conditions for IL-6 consisted of denaturation at $95^{\circ} \mathrm{C}$ for $30 \mathrm{sec}$, annealing at $62^{\circ} \mathrm{C}$ for $40 \mathrm{sec}$ and extension at $72^{\circ} \mathrm{C}$ for $40 \mathrm{sec}$ for 36 cycles. PCR was performed using the Taq Polymerase Master Mix (Qiagen, Inc.). The PCR products were visualized and photographed under UV illumination. The primer sequences used were as follows: IL-6 (628 bp), 5'-ATG AAC TCC TTC TCC ACA AGC GC-3' (sense) and 5'-G AAG AGC CCT CAG GCT GGA CTG-3' (antisense); IL-8 (295 bp), 5'-ACT TCC AAG CTG GCC GTG GCT CTC TTG GCA-3' (sense) and 5' TGA ATT CTC AGC CCT CTT CAA AAA CTT CTC-3' (antisense).

Detection of PCNA and cyclin DI by western blotting. Expression of PCNA and cyclin D1 proteins was analyzed in $\mathrm{CaCo} 2$ cells. After treatment with PBIT and PBI-Se for $24 \mathrm{~h}$, cells were harvested and lysed in lysis buffer [50 mM Tris- $\mathrm{HCl}$ (pH 8.0), $150 \mathrm{mM} \mathrm{NaCl,} 5$ mM EDTA, 1\% NP-40, $1 \mathrm{mM}$ phenylmethylsulfonyl fluoride (PMSF)] on ice. After centrifugation, supernatants were collected and the protein content was measured using a Bio-Rad protein assay kit with bovine serum albumin (BSA) as a standard. Equal amounts of 


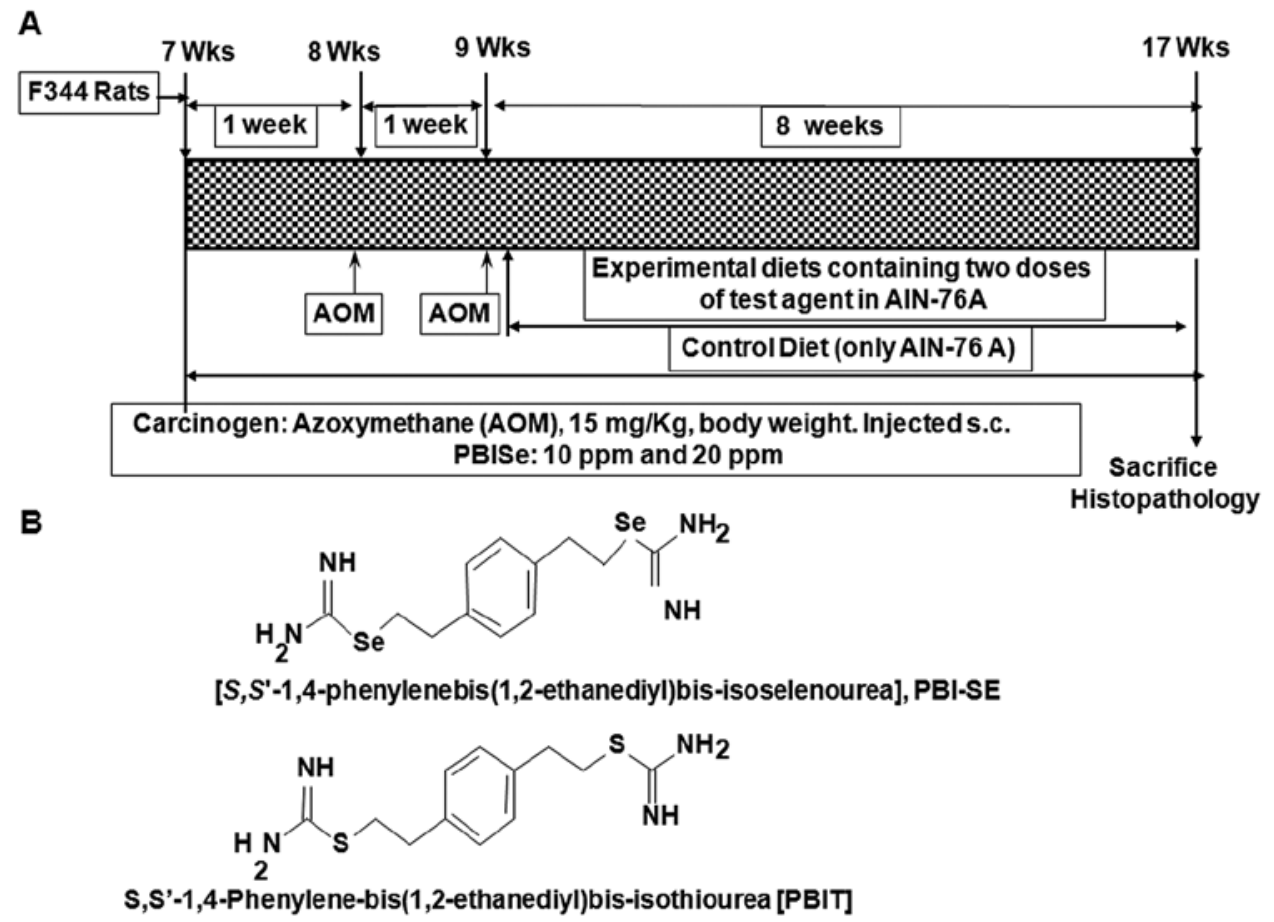

Figure 1. (A) Experimental design for evaluation of the chemopreventive efficacy of PBI-Se in F344 rats. Groups of rats (12 rats/group) were fed the AIN-76A diet starting at 7 weeks of age, treated twice with AOM in their 8th week, and started 3 days later on diets containing 0,10 or 20 ppm PBI-Se, when rats were 9 weeks old. The study was terminated after 53 days of exposure to the experimental diets. (See Materials and methods for more details). (B) Chemical structures of PBI-Se and PBIT.

protein from each extract were separated via polyacrylamide gel electrophoresis (PAGE) in $8 \%$ sodium dodecyl sulfate (SDS) and transferred onto nitrocellulose membranes (Toyo Roshi Kaisha, Ltd., Tokyo, Japan) using the Bio-Rad electrotransfer system. Blots were blocked by incubating in 5\% milk with Tris- $\mathrm{HCl}(\mathrm{pH} 7.5)$ and $0.1 \%$ Tween-20 for $1 \mathrm{~h}$ at room temperature and probed overnight at $4{ }^{\circ} \mathrm{C}$ with rabbit anticyclin D1 polyclonal antibody (Santa Cruz Biotechnology) for cyclin D1 protein and mouse anti-PCNA monoclonal antibody (Santa Cruz Biotechnology) for PCNA. Antibodies were diluted $1: 1,000$ with $5 \%$ milk in Tris- $\mathrm{HCl}(\mathrm{pH} 7.5)$ and $0.1 \%$ Tween-20. The immunoblots were then probed with horseradish peroxidase-conjugated anti-rabbit IgG for cyclin D1 and horseradish peroxidase-conjugated anti-mouse $\operatorname{IgG}$ for PCNA [1:2,000 diluted with 5\% milk in Tris- $\mathrm{HCl}(\mathrm{pH} 7.5)]$. After the final wash, the signal was detected with an enhanced chemiluminescence kit (Pierce Biotechnology, Inc., Rockford, IL, USA).

\section{In vivo experiments}

Animals, diet and care. All animal experiments were carried out in accordance with the NIH guidelines and the University of Oklahoma Health Sciences Center Institutional Animal Care and Use Committee approved protocol. Male F344 rats were obtained from Harlan Laboratories, housed under standardized conditions $\left(21^{\circ} \mathrm{C}, 60 \%\right.$ relative humidity, $12 \mathrm{~h}$ light/12 h dark cycle, 20 air changes/h), and fed a standard laboratory rodent chow and drinking water through reverse osmosis until initiation of the experiment. Prepared diets were based on the modified AIN-76A containing 5\% corn oil by weight (American Institute of Nutrition). The experimental diets contained $0.001 \%$ (10 ppm) or $0.002 \%$ (20 ppm) PBI-Se.
PBI-Se was premixed with a small quantity of casein and then blended into the bulk diet using a Hobart Mixer. Both control and experimental diets were prepared weekly and stored in a cold room. Rats were allowed ad libitum access to the respective diets and tap water.

Experimental design for the efficacy of PBI-Se. The experiment was designed to evaluate the efficacy of 0,10 and $20 \mathrm{ppm}$ of PBI-Se administered continuously starting 3 days after carcinogen treatment. The dose selection was based on our maximum tolerated dose (MTD) study. At 7 weeks of age, groups of rats $[\mathrm{n}=12$ rats per treatment group, $12 \mathrm{AOM}$-treated plus 6 vehicle (saline)-treated] were fed the control diet. At 8 weeks of age, rats intended for carcinogen treatment were injected s.c. with azoxymethane (AOM; Midwest Research Institute, Kansas City, MO, USA) at a dose rate of $15 \mathrm{mg} / \mathrm{kg}$ body weight once weekly for 2 weeks, and those intended for vehicle treatment received an equal volume of normal saline. The experimental diets were initiated 3 days later and continued until termination of the experiment 8 weeks later (Fig. 1). Rats were sacrificed by $\mathrm{CO}_{2}$ euthanasia, and all organs were examined grossly. Colons were evaluated for aberrant crypt foci (ACF). For this evaluation, they were slit open lengthwise from the anus to the ceacum and then fixed flat with the mucosa on the upper side between filter papers in $10 \%$ buffered formalin.

Quantification of ACF. Topographical analysis of the colonic mucosa was carried out according to Bird (22) and our previous report (23). After a minimum of $24 \mathrm{~h}$, fixed colons were stained with $0.2 \%$ methylene blue solution for 5-10 min, placed mucosal side up on a microscopic slide, and viewed 
A
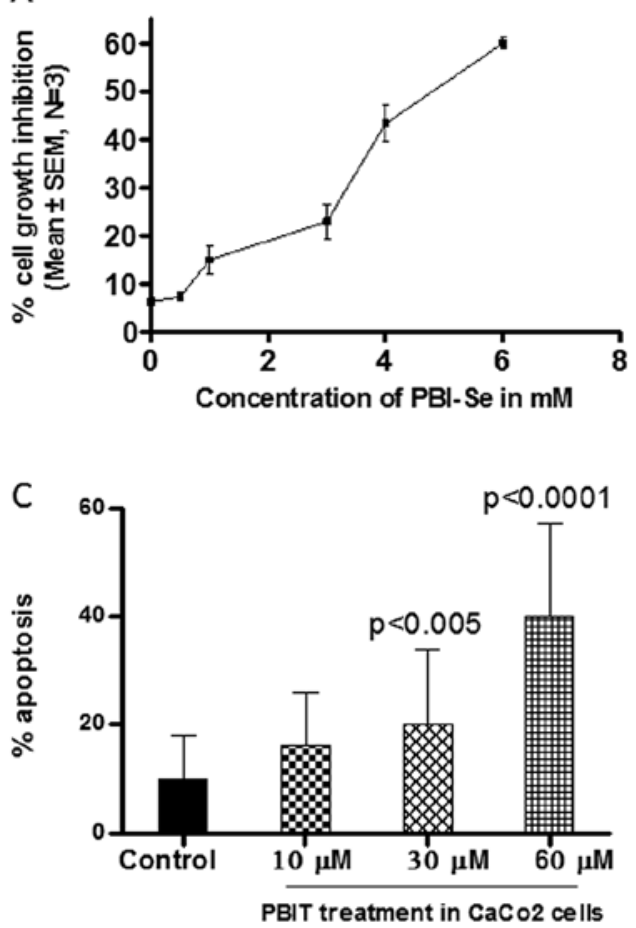

B
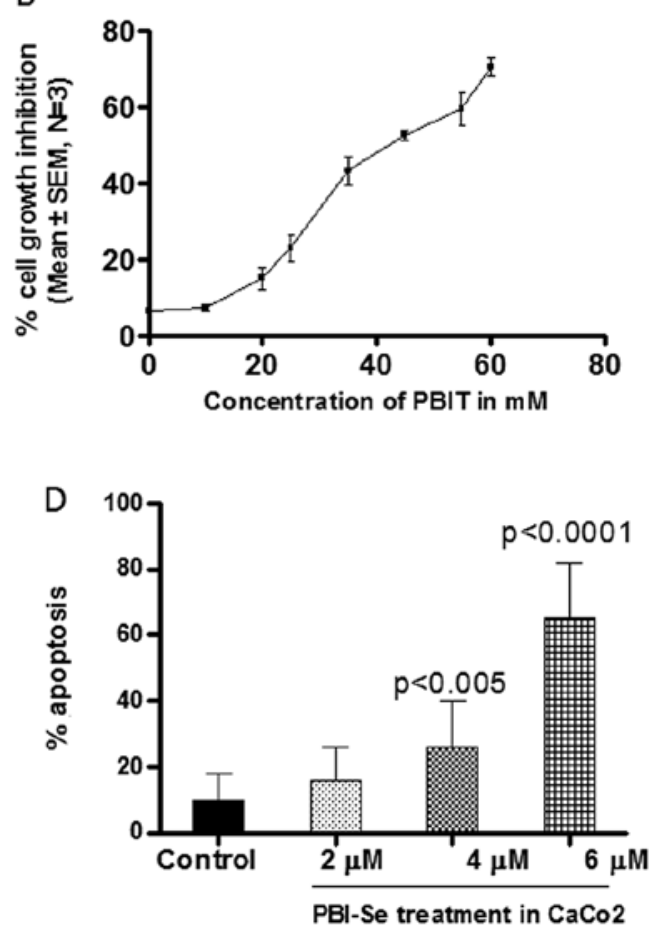

Figure 2. (A) Effect of PBI-Se (2-8 $\mu \mathrm{M}$ for $24 \mathrm{~h})$ on CaCo2 cell proliferation as measured with a Trypan blue viability assay. Only cells that excluded dye were counted as viable. Points are the means of 3 independent experiments; bars, SEM. (B) Effect of PBIT $(0-70 \mu \mathrm{M}, 24 \mathrm{~h})$ on CaCo2 cell proliferation as measured by Trypan blue dye exclusion. Points are the means of 3 independent experiments; bars, SEM. (C) Effect of PBIT (10-60 $\mu \mathrm{M}, 24 \mathrm{~h})$ and (D) effect of PBI-Se $(2-6 \mu \mathrm{M})$ on $\mathrm{CaCo} 2$ cell apoptosis, as determined by acridine orange and ethidium bromide staining. Points are the means of 3 independent experiments; bars, SE. ${ }^{* * *}$ Values significantly different from control by unpaired t-test after Welch's correction with $\mathrm{P}<0.005$ and $\mathrm{P}<0.0001$ for 30 and $60 \mu \mathrm{M} \mathrm{PBIT}$ or 4 and $6 \mu \mathrm{M}$ PBI-Se, respectively.

under a light microscope. The total number of ACF in the entire colon was determined in every $2-\mathrm{cm}$ section of the colon, starting from the distal (taken as $0 \mathrm{~cm}$ ) to the proximal end of the colon. Aberrant crypts were distinguished from the surrounding normal crypts by their increased size, increased distance of cells from lamina to basal surfaces, and easily discernible pericryptal zone. The variables used to assess the aberrant crypts were incidence and multiplicity. Aberrant crypt multiplicity was determined as the number of crypts in each focus and categorized as containing up to 4 or more aberrant crypts per focus.

Giemsa staining of the spleens. Spleens from untreated and treated animals were fixed in formalin, sectioned $(4 \mu \mathrm{m})$, and stained with Giemsa to enumerate the number of polymorphic nuclear cells (PMNs). The percentages of PMNs were calculated relative to control untreated spleens.

Statistical analysis. All the results are reported as the means \pm SE. Statistical differences between control and treated groups were evaluated using the unpaired t-test with Welch's correction. Differences between groups were considered significant at $\mathrm{P}<0.05$.

\section{Results}

Effect of PBIT and PBI-Se on the proliferation of Caco2 cells. $\mathrm{Caco} 2$ cells were exposed for $24 \mathrm{~h}$ in the presence or absence of a cytokine mixture (IL-1 $\beta$, TNF $\alpha+$ IFN $\gamma$ ), or to LPS and to
PBIT $(0-100 \mu \mathrm{M})$ or PBI-Se $(1-12 \mu \mathrm{M})$. As shown in Fig. 2A and $\mathrm{B}$, both iNOS inhibitors caused dose-dependent growth inhibition as determined using a Trypan blue dye exclusion assay. After $24 \mathrm{~h}$ of exposure, 50\% inhibition of cell growth was achieved at $40 \mu \mathrm{M}$ PBIT or at $4 \mu \mathrm{M}$ PBI-Se. PBI-Se induced significant toxicity in $\mathrm{Caco} 2$ cells at or above $6 \mu \mathrm{M}$, whereas PBIT induced significant toxicity at or above $60 \mu \mathrm{M}$. These results demonstrate that PBI-Se is more potent than PBIT.

Effect of PBI-Se and PBIT on apoptosis in Caco2 cells. We observed apoptotic bodies by staining the cells exposed to PBIT or PBI-Se with ethidium bromide and acridine orange. The population of apoptotic cells was enhanced significantly $(\mathrm{P}<0.0002)$ in the PBI-Se-treated cells. As shown in Fig. 2D PBI-Se induced apoptosis in Caco 2 cells in a dose-dependent manner $(5.6 \%$ at $2 \mu \mathrm{M}, 24 \%$ at $4 \mu \mathrm{M}$ and $60 \%$ at $6 \mu \mathrm{M}$ vs. the untreated cells).

Effect of PBI-Se and PBIT on IL-6 and IL-8 in Caco2 cells induced with a cytokine mixture. The inflammatory cytokine response (IL-6 and IL-8) was measured in 3-week cultured Caco- 2 cells induced with the cytokine mixture (TNF $\alpha$ plus IL-1 $\beta+$ IFN $\gamma$ ). We identified basal IL-8 production in $\mathrm{CaCo} 2$ cells, whereas no IL- 6 production was noted in the control cells (in the absence of stimulation with the cytokine mixture). As shown in Fig. 3A, stimulation with the cytokine mixture for $24 \mathrm{~h}$ caused a significant induction in IL-6 and $\sim 50$-fold increase in IL-8. Treatment with PBIT (30 and $60 \mu \mathrm{M}$ ) 
A
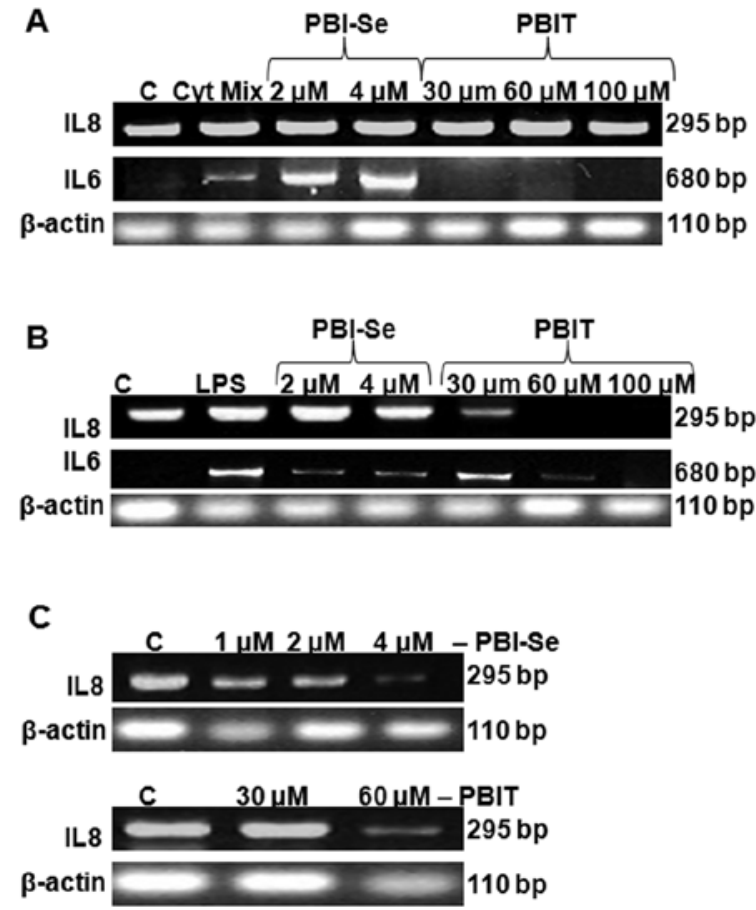

D

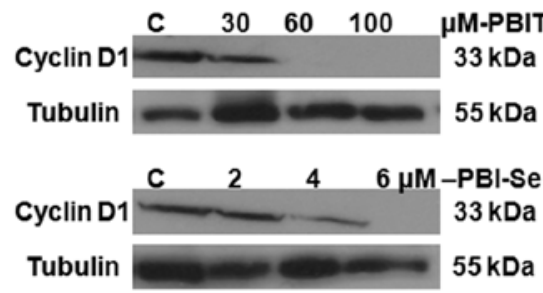

E

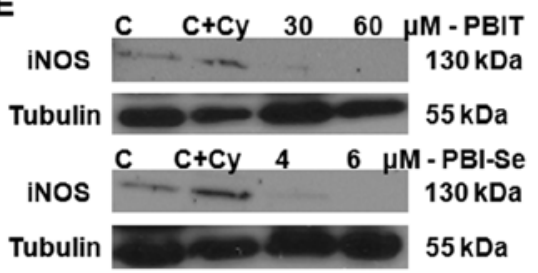

Figure 3. Effect of PBI-Se (2-4 $\mu \mathrm{M})$ and PBIT (30-100 $\mu \mathrm{M})$ on IL-8 and IL-6 mRNA expression induced by (A) a cytokine mixture or (B) by LPS. PBIT suppressed IL-8 and IL- 6 mRNA expression induced in the human colon cancer $\mathrm{CaCo} 2$ cell line by the cytokine mixture and suppressed IL- 6 mRNA production induced by LPS. PBI-Se also suppressed LPS-induced IL-6 mRNA expression, but enhanced IL-6 production in response to the cytokine mixture. (C) PBIT $(1-4 \mu \mathrm{M})$ and PBI-Se (30-100 $\mu \mathrm{M})$ treatment reduced endogenous IL-8 mRNA expression in CaCo2 cells. (D) CaCo2 cells were treated with increasing concentrations of PBI-Se or PBIT for $24 \mathrm{~h}$ and cell lysates were immunoblotted with antibodies against cyclin D1 and $\alpha$-tubulin. Both drugs were effective in decreasing the cyclin D1 protein expression. (E) CaCo2 cells were treated with PBI-Se (at 4 and $6 \mu \mathrm{M}$ ) and PBIT (at 0, 30, 60 and $100 \mu \mathrm{M}$ ) for $24 \mathrm{~h}$. Cell lysates were immunoblotted using antibodies against iNOS and $\alpha$-tubulin. Both the drugs were effective in suppressing iNOS protein expression.

significantly decreased IL-6 at both doses tested, whereas treatment with PBI-Se caused a significant dose-dependent increase in cytokine-induced IL-6. There was no blockage of IL- 8 by either drug. Taken together, the results indicate that inflammatory responses are increased by treatment of Caco-2 cells with the cytokine mixture and that PBIT, but not PBI-Se, can block the IL- 6 component of the response.

Effect of PBI-Se and PBIT on expression of IL-6 and IL-8 in $\mathrm{CaCo} 2$ cells induced with LPS. We also incubated $\mathrm{CaCo} 2$ cells with LPS, in the presence or absence of NOS inhibitors PBIT or PBI-Se for $24 \mathrm{~h}$. PBIT significantly attenuated the LPS-induced IL-6 and IL-8 production in a dose-dependent manner. PBI-Se also dose-dependently attenuated LPS-stimulated IL-6 production but not LPS-stimulated IL-8 production (Fig. 3B), whereas, both the drugs decreased endogenous production of IL-8 in $\mathrm{CaCo} 2$ cells (Fig. 3C).

Effect of PBI-Se and PBIT on iNOS and cyclin DI in CaCo2 cells. A significant dose-dependent decrease in cyclin D1 protein expression was observed with both iNOS inhibitors, suggesting inhibition of cell cycle progression (Fig. 3D). As expected, treatment of $\mathrm{Caco} 2$ cells with $\mathrm{PBI}-\mathrm{Se}$ and PBIT caused a significant inhibition of cytokine-induced iNOS protein expression (Fig. 3E).

Effect of PBI-Se on ACF formation in rats. An initial examination of the effect of PBI-Se on AOM-induced colon carcinogenesis was carried out in rats. Efficacy endpoints used were inhibition of total ACF number as well as reduction in the number of multicrypt clusters (4 or more) of aberrant crypts. Rats that were treated with saline and fed the control or experimental diets showed no evidence of ACF formation in the colon (data not shown). In rats fed the control diet, AOM treatment induced, on average, $\sim 130 \mathrm{ACF} / \mathrm{colon}$, out of which 32 foci contained multiple (4 or more) aberrant crypts/focus (Fig. 4A). ACF were observed predominantly in the distal colons. PBI-Se was found to be an effective inhibitor of total $\mathrm{ACF} /$ colon $(32-41 \%, \mathrm{P}<0.001)$ and of multicrypt clusters containing 4 or more crypts/focus (29-47\%, $\mathrm{P}<0.001)$ (Fig. 4B).

Effect of PBI-Se on PMNs in spleen. Selenium is essential for cell mediated immunity which includes destruction of neoplastic cells (24). Hence, the effect of selenium in the diet on the number of PMNs was analyzed in the spleens of rats fed with the PBI-Se diet. Supplementation of rat diets with PBI-Se increased the percentage of PMNs in the spleens $(\mathrm{P}<0.002$; Fig. 4C and D).

\section{Discussion}

In a quest to identify and characterize better compounds for chemoprevention, an isosteric selenium analog of the known iNOS inhibitor PBIT, was synthesized and tested in vitro and in vivo along with PBIT for comparison. PBI-Se and PBIT both caused a decrease in proliferation of $\mathrm{Caco} 2$ intestinal epithelial cells attributable to inhibition of DNA synthesis (Fig. 2). The $\mathrm{IC}_{50}$ for inhibition by PBI-Se was 3-4 $\mu \mathrm{M}$, which 


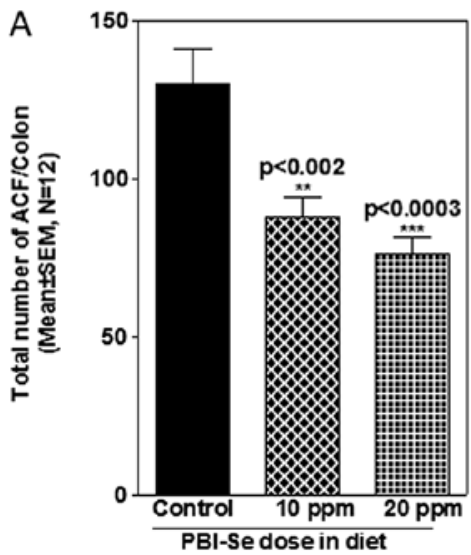

C

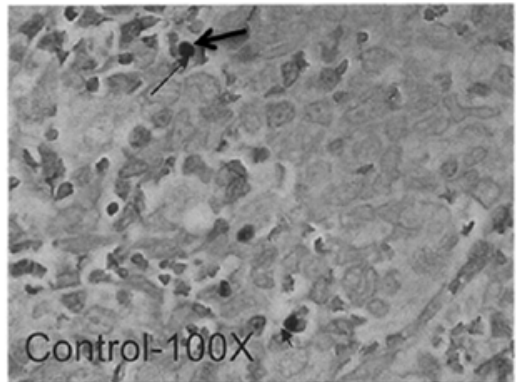

B

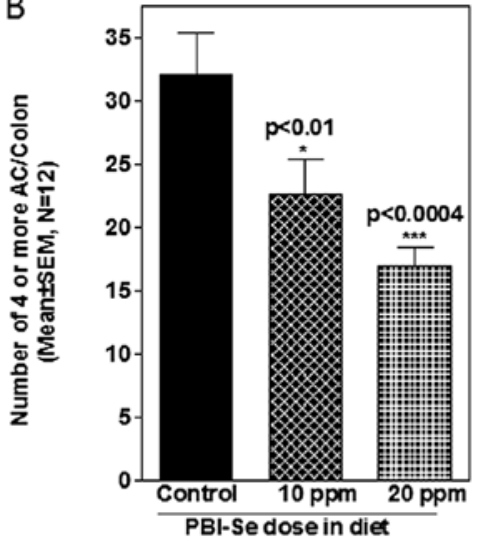

\section{D}
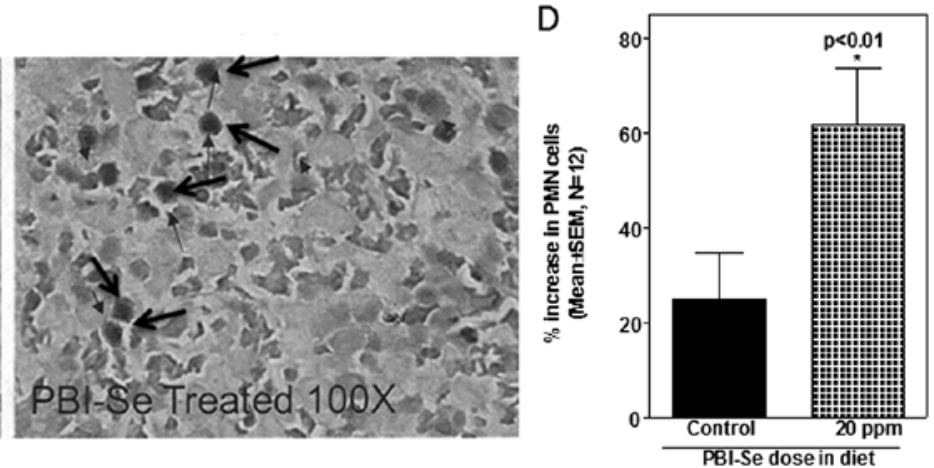

Figure 4. (A) Suppression of AOM-induced total ACF in F344 rats ( $\mathrm{n}=12$ rats/group) by PBI-Se. Results are presented as means \pm SEM. PBI-Se caused a significant dose-dependent decrease in total ACF. (B) Effect of PBI-Se on the number of AOM-induced ACF with four or more crypts/focus in F344 rats ( $n=12$ rats/group). ACF were counted under a microscope after methylene blue staining. Results are presented as the means \pm SEM. PBI-Se caused significant inhibition $(\mathrm{P}<0.0001$, by unpaired t-test with Welch's correction) of foci with four or more aberrant crypts compared with the control groups. (C) Effect of PBI-Se on PMNs in spleen sections of F344 rats. Spleen sections were stained with Giemsa and observed under an oil immersion lens. Black arrows indicate the PMNs in spleen sections. An increased number of PMNs was observed in PBI-Se-treated spleens compared with control spleens. (D) Quantification of the effect of PBI-Se on the number of PMNs in spleen. Points are the means of 12 different fields; bars, SE. ${ }^{*}<<0.01$, significantly different from the control by unpaired t-test with Welch's correction. ACF, aberrant crypt foci.

is consistent with previously published data showing growth inhibition in melanoma cell lines (25). Cell cycle arrest can be achieved by a decrease in the levels of cyclins and/or associated cyclin-dependent kinases (CDKs) (26) and this is evident in the $\mathrm{Caco} 2$ cell line by a decrease in cyclin D1 protein expression with both PBI-Se and PBIT (Fig. 3D).

Intestinal epithelial cells have the potential to express and secrete a wide array of inflammatory cytokines (including chemokines such as IL-8), which may function as signals to neighboring immune and inflammatory cells, initiating and amplifying an ongoing acute immune response (27-29). Numerous studies have shown that IL-8 and iNOS may be expressed in a variety of cells in the setting of inflammation. It has been reported that selenium supplementation in individuals results in induction of TNF $\alpha$, IL-1 $\beta$, IL-8, superoxide dismutase (SOD)2, chemokine (C-X-C motif) ligand 2 (CXCL2) and several other immunological and oxidative stress-related genes (30). IL-8 was reported to inhibit significantly the growth of intraperitoneal and subcutaneous tumors induced by transplantation of K562 cells and to induce cell death by apoptosis in these cells in vivo $(31,32)$. IL-8 production can be increased after stimulation with a mixture of IL-1 $\beta$, IFN $\gamma$ and TNF $\alpha$ in a variety of cells $(33,34)$.

Previous studies also demonstrated that Caco-2 cells grown in a non-co-culture system increased IL- 8 protein and mRNA in response to a wide range of LPS concentrations (20). We observed high endogenous expression of IL-8 in unstimulated $\mathrm{Caco} 2$ cells and enhanced expression when the cells were stimulated with a mixture of IL-1 $\beta$, IFN $\gamma$ and TNFa or with LPS (Fig. 3A and B). Both PBIT and PBI-Se inhibited control endogenous IL-8 production (Fig. 3C). PBIT inhibited LPS-stimulated IL-8 production but not the cytokine-stimulated IL-8 production, whereas comparable growth inhibitory concentrations of PBI-Se did not decrease IL-8 in either stimulation condition (Fig. 3A and B). These results suggest that LPS and proinflammatory cytokines use different cell signaling pathways in colon cancer epithelial cells and that PBI-Se, unlike PBIT, does not interfere with LPS-enhanced IL- 8 production. The induction of IL-8 has important biologic consequences for control of tumor growth. Lee et al (35) showed that the introduction of IL-8, a chemoattractant for neutrophils, basophils and a subset of T-cells, into human ovarian tumors resulted in massive granulocytic and monocytic infiltration and subsequent reduction or elimination of tumor growth. Very high levels of IL- 8 can be associated with increased risk of death (36) (in which cases, PBIT but not PBI-Se might be efficacious in decreasing the toxicity). IL- 8 is an important mediator of the innate immune system response and maintenance of this chemokine by PBI-Se but not PBIT in the presence of LPS supports previous findings 
of the beneficial effects of selenium on the immune system. The results also are consistent with the observation that people with acute and severe illness who develop inflammation and widespread infection often have decreased levels of selenium in their blood (37).

A more dramatic difference between PBI-Se and PBIT was observed in their effects on IL-6 production. PBIT decreased both LPS- and cytokine-stimulated IL-6 production. At comparable growth inhibitory concentrations, PBI-Se had a significant effect on the large LPS-induced IL-6 production and actually increased the lesser cytokine-induced IL-6 production. IL-6 is one of the major mediators of the inflammatory response and is implicated in inflammation, tumor growth and angiogenesis. In patients with active ulcerative colitis, there are increased concentrations of IL- 6 and IL- 8 in the mucosa (38). These results suggest that PBI-Se is able to inhibit only the LPS-induced activation pathway. These divergent effects of PBIT and PBI-Se on IL-6 production require further investigation but suggest that PBI-Se and PBIT have different mechanisms of action and may have different chemopreventive/therapeutic niches. Blunting production of proinflammatory cytokines and/or enhancing anti-inflammatory factors to obtain a balance may become very important. Our results confirm previous findings that show that PBIT suppressed the inducible isoforms of NOS and cyclooxygenase (COX) and also that PBI-Se was effective in inhibiting both iNOS and cyclin D1. These two agents demonstrate that they reduce inflammatory responses in intestinal epithelial cells.

There is a great deal of evidence indicating that selenium supplementation at high levels reduces the incidence of cancer in animals. More than two-thirds of over 100 published studies in 20 different animal models of spontaneous, viral, and chemically induced cancers found that selenium supplementation significantly reduces tumor incidence (39). Observational studies indicate that death from cancer, including lung, colorectal and prostate cancers, is lower among people with higher blood levels or intake of selenium (40-46). The incidence of prostate, colorectal and lung cancer was notably lower in the group given selenium supplements (47). In the present study, PBI-Se was more potent than PBIT at inhibiting Caco2 growth in vitro and administration of PBI-Se provided up to $41 \%$ inhibition of AOM-induced total ACF formation, and suppression in growth of foci with 4 or more crypts by $\geq 47 \%$. These results clearly support the potential colon tumor inhibitory properties of PBI-Se (Fig. 4A and B). However, a previous study showed that dietary administration of Se-free PBIT at $50 \mathrm{ppm}$ could suppress the total number of ACF/colon by $\sim 58 \%$ and aberrant crypt multiplicities by $78 \%$, compared with a control diet (18). Although differential inhibition of IL-6 and IL- 8 by the two inhibitors may contribute to the apparent reversal in order of efficacy of the two iNOS inhibitors in vivo, the difference may be due to different experimental designs. In the present study, animals were fed PBI-Se after the AOM injections, whereas in the previous study, PBIT was administered before AOM treatments. Also, the PBI-Se dose used here post-initiation was $50 \%$ less than the dose of PBIT used previously in the chemoprevention protocol. Our pre-clinical results are consistent with previous clinical observations with other forms of selenium (selenomethionine) showing lowered risk of developing prostate, lung and colorectal cancer in a large scale cancer prevention trial (48). Although the exact mechanism by which PBI-Se acts cannot be determined, the present findings highlight the need for further research on the potential interactions between epithelial cells and immune cells under different inflammatory conditions with activation of varied signaling pathways.

Certain breakdown products of selenium have been suggested to prevent tumor growth by enhancing immune cell activity and suppressing development of blood vessels to the tumor (49). There is accumulating evidence that selenium deficiency may contribute to the development of a form of heart disease, hypothyroidism, and a weakened immune system $(50,51)$. At the doses used, the selenium in PBI-Se may have enhanced immune system function and affected carcinogen metabolism. Selenium is an essential component of thyroid metabolism and antioxidant defense, as well as immune function. It appears to improve activation and proliferation of B-lymphocytes and to enhance T-cell function. It is also involved in several key metabolic activities through selenoprotein enzymes that protect against oxidative damage (52). In one randomized study of free-living, healthy humans (57-84 years of age), those given $400 \mathrm{mcg} / \mathrm{day}$ of selenium for 6 months had a $65 \%$ increase in $\mathrm{T}$ cells, particularly CD4 cells, and a 58\% increase in NK cell cytotoxicity (53). Studies on the effects of selenium deficiency on HIV connected selenium levels to $\mathrm{T}$ cell function and apoptosis suggesting that selenium may enhance resistance to infection by modulating IL production and $\mathrm{T}$ helper cell responses (54). The increased number of PMNs in the PBI-Se-treated rat spleens suggests an effect on immune cells which may have an important role in inducing apoptotic effects in the colon cancer cells.

Recently, a large randomized, placebo-controlled intervention study, the SELECT study, found that $200 \mathrm{mcg} / \mathrm{day}$ of selenium did not alter the risk of prostate cancer (55). However, a phase III clinical trial at NIH using selenium for chemoprevention therapy to try to prevent the development of neoplasia in the prostate is underway. Animal studies suggest that mammary tumors are significantly reduced by selenium, and a study in women that should yield more definitive information on this relationship is presently underway (56). The present study shows that PBI-Se is a more potent growth inhibitory agent in vitro than its isosteric sulfur analog PBIT and that it does not decrease cytokine- or LPS-stimulated IL-8 production. Both in vivo and in vitro data support the development of PBI-Se for prevention and treatment of colon cancer.

\section{Acknowledgements}

The authors thank Dr Julie Sando for her valuable suggestions and for editing the article. The authors also thank the OUHSC Rodent Barrier Facility staff for their support for bioassay studies.

\section{References}

1. American Cancer Society. Colorectal cancer key statistics. Available at: http://www.cancer.org/Cancer/ColonandRectum Cancer/DetailedGuide colorectal-cancer-key-statistics.

2. Jackson JR, Seed MP, Kircher CH, Willoughby DA and Winkler JD: The codependence of angiogenesis and chronic inflammation. FASEB J 11: 457-465, 1997. 
3. Phoa $\mathrm{N}$ and Epe $\mathrm{B}$ : Influence of nitric oxide on the generation and repair of oxidative DNA damage in mammalian cells. Carcinogenesis 23: 469-475, 2002.

4. Jaiswal M, LaRusso NF, Burgart LJ and Gores GJ: Inflammatory cytokines induce DNA damage and inhibit DNA repair in cholangiocarcinoma cells by a nitric oxide-dependent mechanism. Cancer Res 60: 184-190, 2000.

5. Moore MA: Cytokine and chemokine networks influencing stem cell proliferation, differentiation, and marrow homing. J Cell Biochem 38: 29-38, 2002.

6. Nakajima N, Kuwayama H, Ito Y, Iwasaki A and Arakawa Y: Helicobacter pylori, neutrophils, interleukins, and gastric epithelial proliferation. J Clin Gastroenterol 25: S198-S202, 1997.

7. Eberhart CE, Coffey RJ, Radhika A, Giardiello FM, Ferrenbach S and DuBois RN: Up-regulation of cyclooxygenase 2 gene expression in human colorectal adenomas and adenocarcinomas. Gastroenterology 107: 1183-1188, 1994.

8. Rhodes JM and Campbell BJ: Inflammation and colorectal cancer: IBD-associated and sporadic cancer compared. Trends Mol Med 8: 10-16, 2002.

9. Keshavarzian A, Fusunyan RD, Jacyno M, Winship D, MacDermott RP and Sanderson IR: Increased interleukin-8 (IL-8) in rectal dialysate from patients with ulcerative colitis: evidence for a biological role for IL-8 in inflammation of the colon. Am J Gastroenterol 94: 704-712, 1999.

10. Nusrat A, Sitaraman SV and Neish A: Interaction of bacteria and bacterial toxins with intestinal epithelial cells. Curr Gastroenterol Rep 3: 392-398, 2001.

11. Weiss HA and Forman D: Aspirin, non-steroidal anti-inflammatory drugs and protection from colorectal cancer: a review of the epidemiological evidence. Scand J Gastroenterol 220: 137-141, 1996.

12. Jenkins DC, Charles IG, Thomsen LL, et al: Roles of nitric oxide in tumour growth. Proc Natl Acad Sci USA 92: 4392-4396, 1995

13. Ambs S, Merriam WG, Bennett WP, et al: Frequent nitric oxide synthase-2 expression in human colon adenomas: implication for tumour angiogenesis and colon cancer progression. Cancer Res 58: 334-341, 1998

14. Jobin C, Haskill S, Mayer L, Panja A and Sartor RB: Evidence for altered regulation of I kappa B alpha degradation in human colonic cells. J Immunol 158: 226-234, 1997.

15. Knowles RG and Moncada S: Nitric oxide synthases in mammals Biochem J 298: 249-258, 1994.

16. Forstermann U, Gath I, Schwarz P, Closs EI and Kleinert H: Isoforms of nitric oxide synthase. Properties, cellular distribution and expressional control. Biochem Pharmacol 50: 1321-1332, 1995.

17. Pana $\mathrm{MH}$ and Ho CT: Chemopreventive effects of natural dietary compounds on cancer development. Chem Soc Rev 37 2558-2574, 2008.

18. Rao CV, Kawamori T, Hamid R and Reddy BS: Chemoprevention of colonic aberrant crypt foci by an inducible nitric oxide synthase-selective inhibitor. Carcinogenesis 2: 641-644, 1999.

19. Briske-Anderson MJ, Finley JW and Newman SM: The influence of culture time and passage number on the morphological and physiological development of $\mathrm{CaCo} 2$ cells. Proc Soc Exp Biol Med 214: 248-257, 1997.

20. Huang Y, Li N, Liboni K and Neu J: Glutamine decreases lipopolysaccharide-induced IL-8 production in Caco-2 cells through a non-NF-kappaB p50 mechanism. Cytokine 22: 77-83, 2003.

21. Chittezhath M, Deep G, Singh RP, Agarwal C and Agarwal R: Silibinin inhibits cytokine-induced STATs, MAPKs, NF- $\kappa$ B and AP-1 activation, and down-regulates HIF-1 $\alpha$ and iNOS in human lung carcinoma A549 cells. Mol Cancer Ther 7: 1817-1826, 2008.

22. Bird RP: Observation and quantification of aberrant crypts in the murine colon treated with a colon carcinogen: preliminary findings. Cancer Lett 37: 147-151, 1987.

23. Janakiram NB, Mohammed A, Zhang Y, Choi CI, Woodward C, Collin P, Steele VE and Rao CV: Chemopreventive effects of Frondanol A5, a Cucumaria frondosa extract, against rat colon carcinogenesis and inhibition of human colon cancer cell growth. Cancer Prev Res 3: 82-91, 2010.

24. Arthur JR, McKenzie RC and Beckett GJ: Selenium in the immune system. J. Nutr 133: S1457-S1459, 2003.

25. Chung CY, Madhunapantula SV, Desai D, Amin S and Robertson GP: Melanoma prevention using topical PBI-Se. Cancer Prev Res 4: 935-948, 2011.
26. Vermeulen K, Van Bockstaele DR and Berneman ZN: The cell cycle: a review of regulation, deregulation and therapeutic targets in cancer. Cell Prolif 36: 131-149, 2003.

27. Fusunyan RD, Quinn JJ, Fujimoto M, MacDermott RP and Sanderson IR: Butyrate switches the pattern of chemokine secretion by intestinal epithelial cells through histone acetylation. Mol Med 5: 631-640, 1999.

28. Ogle CK, Guo XL, Hasselgren PO, Ogle JD and Alexander JW: The gut as a source of inflammatory cytokines after stimulation with endotoxin. Eur J Surg 163: 45-51, 1997.

29. Haller D, Bode C, Hammes WP, Pfeifer AMA, Schiffrin EJ and Blum S: Non-pathogenic bacteria elicit a differential cytokine response by intestinal epithelial cell/leucocyte co-cultures. Gut 47: 79-87, 2000

30. Kibriya MG, Jasmine F, Argos M, Verret WJ, Rakibuz-Zaman M, Ahmed A, Parvez F and Ahsan $\mathrm{H}$ : Changes in gene expression profiles in response to selenium supplementation among individuals with arsenic-induced pre-malignant skin lesions. Toxicol Lett 169: 162-176, 2007

31. Terui Y, Ikeda M, Tomizuka $\mathrm{H}$, et al: Identification of a novel apoptosis-inducing factor derived from leukemic cells: endothelial interleukin-8, but not monocyte-derived, induces apoptosis in leukemic cells. Biochem Biophys Res Commun 243: 407-411, 1998.

32. Terui Y, Ikeda M, Tomizuka H, et al: Activated endothelial cells induce apoptosis in leukemic cells by endothelial interleukin-8. Blood 92: 2672-2680, 1998.

33. Hoffmann E, Dittrich-Breiholz O, Holtmann H and Kracht M: Multiple control of interleukin-8 gene expression. J Leukoc Biol 72: 847-855, 2002

34. Garat C and Arend WP: Intracellular IL-1Ra type 1 inhibits IL-1induced IL- 6 and IL-8 production in Caco- 2 intestinal epithelial cells through inhibition of p38 mitogen-activated protein kinase and NF-kappaB pathways. Cytokine 23: 31-40, 2003.

35. Lee Li-F, Hellendall RP, Wang Y, Stephen Haskill J, Mukaida N, Matsushima K and Ting JP: IL-8 reduced tumorigenicity of human ovarian cancer in vivo due to neutrophil infiltration. J Immunol 164: 2769-2775, 2000.

36. Molica S, Vitelli G, Levato D, Levato L, Datillo A and Gandolfo GM: Clinico-biological implications of increased serum levels of interleukin -8 in B cell chronic lymphocytic leukemia. Haematologica 84: 208-211, 1999.

37. Gartner R, Albrich W and Angstwurm MW: The effect of a selenium supplementation on the outcome of patients with severe systemic inflammation, burn, and trauma. Biofactors 14: 199-204, 2001

38. Murata Y, Ishiguro Y, Itoh J, Munakata A and Yoshida Y: The role of pro-inflammatory and immunoregulatory cytokines in the pathogenesis of ulcerative colitis. Gastroenterol Clin North Am J 30: 56-60, 1995 .

39. Combs GF Jr and Gray WP: Chemopreventive agents: selenium. Pharmacol Ther 79: 179-192, 1998.

40. Russo MW, Murray SC, Wurzelmann JI, Woosley JT and Sandler RS: Plasma selenium levels and the risk of colorectal adenomas. Nutr Cancer 28: 125-129, 1997.

41. Patterson BH and Levander OA: Naturally occurring selenium compounds in cancer chemoprevention trials: a workshop summary. Cancer Epidemiol Biomarkers Prev 6: 63-69, 1997.

42. Knekt P, Marniemi J, Teppo L, Heliovaara M and Aromaa A: Is low selenium status a risk factor for lung cancer? Am J Epidemiol 148: 975-982, 1998.

43. Fleet JC: Dietary selenium repletion may reduce cancer incidence in people at high risk who live in areas with low soil selenium. Nutr Rev 55: 277-279, 1997.

44. Shamberger RJ: The genotoxicity of selenium. Mutat Res 154: 28-48, 1985.

45. Young KL and Lee PN: Intervention studies on cancer. Eur J Cancer Prev 8: 91-103, 1999.

46. Burguera JL, Burguera M, Gallignani M, Alarcon OM and Burgueera JA: Blood serum selenium in the province of Merida, Venezuela, related to sex, cancer incidence and soil selenium content. J Trace Elem Electrolytes Health Dis 4: 73-77, 1990.

47. Combs GF Jr, Clark LC and Turnbull BW: Reduction of cancer risk with an oral supplement of selenium. Biomed Environ Sci 10: 227-234, 1997.

48. Clark LC, Combs GF Jr, Turnbull BW, et al: Effects of selenium supplementation for cancer prevention in patients with carcinoma of the skin. A randomized controlled trial. JAMA 276: 1957-1963, 1996.

49. Combs GF Jr, Clark LC and Turnbull BW: An analysis of cancer prevention by selenium. Biofactors 14: 153-159, 2001. 
50. Combs GF Jr: Food system-based approaches to improving micronutrient nutrition: the case for selenium. Biofactors 12 : 39-43, 2000.

51. Zimmerman MB and Kohrle J: The impact of iron and selenium deficiencies on iodine and thyroid metabolism: biochemistry and relevance to public health. Thyroid 12: 867-878, 2002.

52. Ryan-Harshman M and Aldoori W: The relevance of selenium to immunity, cancer and infectious/inflammatory diseases. Can J Diet Pract Res 66: 98-102, 2005.

53. Wood SM, Beckham C, Yosioka A, Darban H and Watson RR Beta-carotene and selenium supplementation enhances immune response in aged humans. Integr Med 2: 85-92, 2000.
54. Baum MK, Miguez-Burbano MJ, Campa A and Shor-Posner G: Selenium and interleukins in persons infected with human immunodeficiency virus type 1. J Infect Dis 182: S69-S73, 2000.

55. Lippman SM, Klein EA, Goodman PJ, et al: Effect of selenium and vitamin $\mathrm{E}$ on risk of prostate cancer and other cancers: the Selenium and Vitamin E Cancer Prevention Trial (SELECT). JAMA 301: 39-51, 2009.

56. Whanger PD: Selenium and its relationship to cancer: an update. Br J Nutr 91: 11-28, 2004. 